\title{
Beyond the Flesh: Contemporary Representations of the Black Female Body in Afro-Brazilian Literature
}

Flávia Santos de Araújo

Smith College, fsantosdearaujo@smith.edu

Follow this and additional works at: https://scholarworks.smith.edu/afr_facpubs

Part of the Africana Studies Commons

\section{Recommended Citation}

Santos de Araújo, Flávia, "Beyond the Flesh: Contemporary Representations of the Black Female Body in Afro-Brazilian Literature" (2016). Africana Studies: Faculty Publications, Smith College, Northampton, MA. https://scholarworks.smith.edu/afr_facpubs/12

This Article has been accepted for inclusion in Africana Studies: Faculty Publications by an authorized administrator of Smith ScholarWorks. For more information, please contact scholarworks@smith.edu 


\section{PROJECT MUSE}

Beyond the Flesh: Contemporary Representations of the Black Female Body in Afro-Brazilian Literature

Flávia Santos de Araújo

Meridians: feminism, race, transnationalism, Volume 14, Number 1, 2016, pp. 148-176 (Article)

Published by Indiana University Press

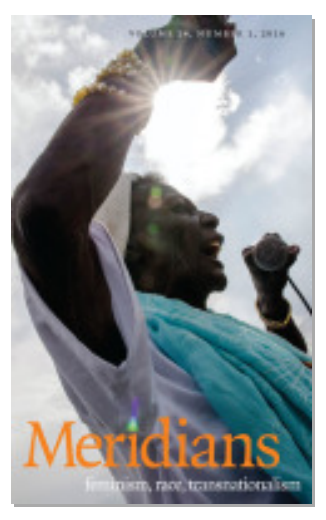

$\Rightarrow$ For additional information about this article https://muse.jhu.edu/article/631824 


\title{
Beyond the Flesh: Contemporary Representations of the Black Female Body in Afro-Brazilian Literature
}

\begin{abstract}
This essay takes an intersectional and transnational approach to analyze how selected poetic texts by contemporary Afro-Brazilian writers Conceição Evaristo, Esmeralda Ribeiro Cristiane Sobral, Miriam Alves, and Elisa Lucinda (re)design portrayals of Afro-descendant/black female bodies. As cultural artifacts, I argue that these poetic/political constructs give evidence of Afro-Brazilian female bodies as historical: on one hand, they represent the embodiment of "otherness" as they historically differ from the standards of (white) "normalcy;" on the other hand, they carry both the silenced histories of racial and sexual exploitation and the appeal of hyper-sexualized and exoticized stereotypes. I am also interested in discussing how these writings/writers articulate notions and images connected to discourses of mestiçagem in order to rewrite black women's bodies into new historical perspectives; how they question long-established national narratives of racial harmony; and how they build dialogues with a more diasporic understanding of black women's cultural and political networking across the Americas. Finally, this essay explores the ways in which contemporary Afro-Brazilian literature opens to the reaffirmation of black female subjectivities from multiple cultural perspectives and identities.
\end{abstract}

Meridians: feminism, race, transnationalism I4, no. I (2016): I48-I76.

Copyright $\odot 2016$ Smith College. doi:Io.2979/meridians.I4.I.Io 


\section{Introduction}

The black female body has continuously been a site of controversy, exploitation, delight, distaste, lust, repulsion, and transformation in the history of the diaspora in the Americas. When discussing the roles and images usually attributed to black women in Brazil in an interview, Afro-Brazilian poet and novelist Conceição Evaristo states:

... espera-se que a mulher negra seja capaz de desempenhar determinadas funções, como cozinhar muito bem, dançar, cantar - mas não escrever. Às vezes, as pessoas olham para mim e perguntam: "Mas você canta?" E eu digo: "Não canto, nem danço." (Evaristo 2006, 96)

[". . . it is expected that a black woman be able to play some specific roles, such as cooking very well, dancing, singing - but not writing. Sometimes, people look at me and ask: 'Do you sing?' I say: 'I neither sing nor dance."”]

Evaristo's statement reveals a prevailing preconceived notion of black women in Brazil. Her words also delineate a more complex, intricate image of the black woman, historically constructed and culturally imposed by colonialist perspectives over black female bodies all over the world, and particularly strongly in the so-called "New World." However, this is not a "new story": it is intrinsically connected to the history of the transatlantic slave trade and slavery in the Americas, a consequence of the economic needs of European colonial projects developed both inside and outside of Africa. ${ }^{\mathrm{I}}$

Inscribed in slavery, the black female body was pushed into a process that sought to promote the legitimation of a system of oppression, subsequently helping to perpetuate a series of stereotypical and derogative images in cultural and social practices. bell hooks explains that, in order to justify the exploitation and sexual violence imposed on enslaved black women, the dominant culture created "an iconography of Black female bodies" as hypersexual- "the perfect embodiment of primitive, unbridled eroticism" (hooks I99I, I53). Therefore, the black female body becomes a site of contradictions in which the tension of desire/repulsion underlines the exploitation and control of black women's labor, sexual reproduction, 
and sexuality: a framework manifested in "two distinct and paradoxical stereotypes-they were disgustingly lustful... but exceptionally unfeminine. They were alluring but unattractive; they attracted and repelled at the same time" (Guy-Sheftall 2002, 23). In Brazil, the contours of this framework is formed by the discourses of mestiçagem ${ }^{2}$ and the myth of racial democracy that creates sociocultural categories for black women within the color spectrum - a phenomenon I call, inspired by bell hooks, the "iconography of mestiçagem."

In this essay, I argue that contemporary Afro-Brazilian women writers are constantly revisiting that historical discourse, rewriting the Afrodescendant body in the historical spectrum and repositioning black women's bodies as historical agents. By creating a contemporary aesthetic that liberates the black female body, Afro-Brazilian writers design literary (re)constructions from multiple perspectives and identities, exposing the cultural and historical complexities and ambivalences that characterize the black female body within the iconography of mestiçagem. For the purpose of this study, I focus on the poetics of Conceição Evaristo, Esmeralda Ribeiro, Cristiane Sobral, Miriam Alves, and Elisa Lucinda, as they represent some of the most prominent and prolific contemporary Afro-Brazilian women writers.

Regarding the black female body as a historical signifier, I also argue that contemporary Afro-Brazilian women's writings re-inscribe Afro-descendant women (and their bodies) into the national historical narrative within two major intersecting movements. I will call one of them "revisionary" because it promotes a re-reading of Brazil's history and the foundations of its national identity. Part of its revisionary objective is to expose both the processes of exploitation and oppression imposed on black bodies and the discourses of mestiçagem and the racial democracy. I will call the second movement "revolutionary" because its discourse engages with the notion of consciousness-raising, promoting self-affirmation and the liberation of black bodies. The revolutionary element of this movement is connected with the solidification of black movements in the country since the late rig7os.

Within this framework, this essay dialogues with the studies developed by Brazilian scholars such as Eduardo de Assis Duarte, Florentina da Silva Souza, Heloisa Toller Gomes, and Maria Nazareth Fonseca, whose 
pioneering works have revisited and questioned the Brazilian literary canon in order to unveil the Afro-Brazilian literary tradition. As a contribution, my analysis of selected writings by contemporary Afro-Brazilian women poets, informed by a transnational, intersectional, and diasporic framework, examines how race, gender, and sexuality intersect to promote what Carole Boyce Davies defines as "multiple and variable subject positions" based on "particular cultural, historical, geopolitical, [and] class communities in which Black women exist" (Davies I994, 9). Although I focus my analysis solely on the poetry of contemporary Afro-Brazilian women writers, this study aspires to connect to further discussions on the ways Afro-descendant women writers articulate and negotiate the body/cultural politics in their work across the African diaspora in the Americas. Therefore, I contend that by rewriting the Afro-descendant female body, identities, and subjectivities—and, most importantly, their histories (or "herstories," to use a term coined by feminist intellectual Robin Morgan)—into literary representations of multi-layered racial, gender, and sexual discourses, contemporary Afro-Brazilian writers challenge the celebratory postmodern discourses that equate hybridity and mestiçagem with the transcendence of racial differentiation and racial divisions. In that sense, these writers use representations of multiple identities to re-elaborate universalizing notions of selfhood and the complexities of subjectivity while retaining a sense of cultural and historical specificity.

Ultimately, considered as a product of the history of the African diaspora in the Americas, these literary representations open up paths in which to re-address the memory of the oppression that marks this history-the embodiment of colonization and conquest as discussed by Patricia Hill Collins (2000, 158-9) - but also to nourish a transformative embodiment that creates space for the liberation and celebration of black female bodies across and beyond borders.

\section{The Iconography of Mestiçagem and the Stereotyping of Black Female Bodies}

Beyond transforming the black female body into a tool and a resource for economic profit, colonization has also made it a peculiar expression 
of "otherness." Drawing upon a series of narratives by male European travelers from the sixteenth to the nineteenth century, historian Jennifer Morgan demonstrates that the bodies of African-descendant women were used as signifiers of racial difference and as evidence of cultural deficiency: "the process by which 'Africans' became 'blacks' who became 'slaves"' (Morgan 2004, I3). In this process, the black female body, placed in dichotomy with the white norm, connoted the inverse mirror image of "beauty" and its contours indicated a lack of femininity. Thus, the male European gaze projects the animalization of the black female body, transforming the black woman, as Morgan declares, into "a monstrous laboring beast" (Morgan 2004, I5).

While having their bodies objectified and then used to serve the purposes of the dominant social system, black women were simultaneously regarded as creatures with no intellectual capabilities. These images, hooks explains, have gradually and progressively been installed in the collective consciousness and reinforce the idea that the black female body belongs to a category placed very far from intellectual life (hooks I99I, I54), as Evaristo also pointed out in her interview.

It is important to note that this male European gaze has always been permeated by an ambivalent combination of sexual desire, a sense of superiority, and repulsion. The white Anglo-Saxon patriarchal Christian set of moral principles and beliefs is not only fundamentally a repressor of sexual impulses and desires, but it also rejects everything that is different from its norm in order to confirm and legitimize the very core of assumptions that constitute its standard of "normalcy." Thus, overwhelmed by the "otherness" of African peoples' bodies, cultures, religions, and social arrangements, Euro-American eyes are both repelled and attracted to their vision of the "other," but this vision is depicted in ways that justify and legitimize its ultimate end-the domination of those who serve as support for the maintenance of the colonial power.

It is through the mechanism of this conflicted and conflict-generating lens that racial ideologies are fundamentally originated and the black bodies of African-descendant women have been stigmatized. In Brazil, the myth of a racially harmonious mestiça nation was constructed as an ideology and has been elaborated as a political strategy by the national elite from the late nineteenth century to the mid-twentieth century. 
Central to this racial ideology is the notion that a progressive process of assimilation by the superior race could overcome the inferiority of the "negro" race; thus, the mestiço" individual, becomes the key element of transition and the ultimate icon of a unified national identity (Costa 200I, I43-2). By manipulating the discourses of mestiçagem, the elites are able to maintain their power structures and a sense of national unity, while acknowledging, in a condescending way, the racial mixture and harmony of the population. In this context, mestiçagem has a powerful political and symbolic meaning in the development of the ideology of branqueamento (whitening) and in the establishment of the notion of racial democracy in the twentieth century.

Anthropologist Kabengele Munanga points out that, although the process of national identity formation in Brazil was based on principles of eugenics, it did not succeed in terms of its project of physically whitening the society (Munanga I999, I5). Despite its failure as a national project to solve the Brazilian "negro problem," the ideal of branqueamento has left deep marks on the Brazilian collective consciousness, as Munanga highlights:

Esse ideal prejudica qualquer busca de identidade baseada na 'negritude' e na 'mestiçagem', já que todos sonham ingressar um dia na identidade branca, por julgarem superior.

["This ideal is an obstacle to any effort to build an identity based on 'blackness' or 'mestiçagem', since everyone dreams of one day integrating the white identity, considered to be superior."] (Munanga I999, I6, my translation)

As Munanga argues, the complicated and contradictory terrain on which Brazilian racial dynamics moves is also the same space that embraces particular cultural expressions of underprivileged groups (indigenous, blacks, and mestiços). For instance, various kinds of Afro-Brazilian music (such as samba and axé music) or indigenous arts and crafts are integrated into Brazilian mainstream culture as symbols of a contemporary national identity, despite the social and political underrepresentation to which Afro-Brazilian communities are subjected. Ultimately, however, that mainstream cultural integration does not promote awareness of the history of the country's diverse racial and ethnic groups and their multicultural 
expressions. Nor does it acknowledge the historical exploitation of large masses of indigenous and African descendant peoples.

Within this particular scenario, how do contemporary Afro-Brazilian women writers articulate notions and images connected to discourses of mestiçagem? How do they rewrite black women's bodies into new historical perspectives? To what extent do their aesthetic projects question longestablished national narratives of racial harmony? And, finally, in what ways does their artistic production create diasporic dialogues, as well as cultural and political networking?

In Brazil, the Afro-descendant female body incorporates a series of different inscribed stereotypes which I call "the iconography of mestiçagem." The politics of miscegenation and the ideology of racial democracy, two fundamental forces that have informed Brazilian racial order for more than three centuries, gave rise to the Brazilian color spectrum and racial hierarchy, predicated on the objectification and sexual exploitation of Afro-Brazilian women. It is important to highlight that the cordiality and intimacy posited by Gilberto Freyre in his 1933 classic, Casa Grande e Senzala (The Masters and the Slaves), rested on the nursery and kitchen duties of AfroBrazilian domestic workers, primarily black women. Kia Lilly Caldwell (2007) demonstrates how the historical construction of the nineteenthcentury ideologia do branqueamento in Brazil accepted intermediate racial types while simultaneously rejecting blackness. As Caldwell argues, this ideology did not contribute to establishing a more egalitarian social structure for mestiços, nor did it help deconstruct degrading images connected with mixed-race populations. In reality, it helped promote notions of mestiço inferiority and contributed to maintaining the political, social and economic hegemony of white elites. In particular, the bodies of Afro-descendant women have been a key element in solidifying the ideology of branqueamento, and, through vessels such as samba and Carnival, the symbolic and concrete appropriation of their bodies has been "vital to the construction of Brazil's identity as a mestiço nation" (Caldwell 2007, 40).

When analyzing how representations of Afro-Brazilian women were created according to the iconography of mestiçagem and the color spectrum of racial hierarchy, it is possible to perceive that Brazilian women of different color categories other than white are placed in unalterable or un-exchangeable social roles. Although some lighter-skinned women, 
such as morenas and mulatas, have access to a restricted social mobility and might even benefit from their status when attempting to enter certain public spaces, their bodies are nonetheless still encoded by the grammar of exoticism, objectification, and sexualization. As icons of mestiçagem, the bodies of Afro-Brazilian women ultimately are subjected to patriarchal guidelines through which miscegenation connects with sexual exploitation. Thus, according to the color spectrum, categories of AfroBrazilian women with darker skin are often associated with domestic labor, while Afro-Brazilian women whose complexions are closer to white standards of beauty are often perceived in sensual or sexualized ways (Caldwell 2007, 5I-2).

Considering literature as a space in which cultural representations are forged, perpetuated, or even challenged, some classic examples in Brazilian literature illustrate some of these iconic associations of Afro-descendant women. One such representation is personified in the characters of Rita Baiana and Bertoleza in the I89o novel 0 Cortiço, by mestiço writer Aluísio Azevedo ${ }^{3}$. While Rita Baiana is the personification of the hyper-sexual mulata, Bertoleza, an enslaved black woman, embodies an unquestionable subservience throughout the narrative. Notably, these representations depict two of the most well-known icons of black women in Brazil: on one hand, the image of the "Mãe Preta"—eternalized by Brazilian painter Lucílio de Albuquerque in his homonymous 1912 canvas-is the figure of an enslaved black woman who generously breastfeeds a white baby; on another hand, we see the eroticized and exotic figure of the sensual, promiscuous mulata, whose exploited body was also used as a source of profit within the colonial economic structure in Brazil.

In the twentieth century, poet Jorge de Lima has also used the image of the demonized mulata in the portrayal of Negra Fulô in his poem "Essa Negra Fulô," published in the 1929 anthology Novos Poemas. The narrative poem describes Fulô as a "pretty" enslaved young black woman working in the slave owner's household, who, accused of theft, is then punished with the whip. The striking aspect of this popular modernist poem by Lima is that the sequence of events, including Fulô's whipping, is described as a game of seduction throughout the poem: Fulô's misbehavior is compensated by the slave owner's vision of her nudity while she is under the whip. 
Another modernist, novelist Jorge Amado, created what is likely one of the most well-known literary representations of mestiço Brazil; his novels have been published in around 49 languages and popularized in film. Amado's 1958 novel Gabriela, Cravo e Canela (Gabriela, Glove and Cinnamon) is iconic in this sense. The light-skinned Gabriela is naïve, but extremely eroticized and objectified: as an exotic and "primitive" figure, she has no control over her sexual impulses and is always sexually available. As a character, Gabriela reinforces the notion of the hyper-sexual, exoticized morena, a stereotype that has played a central role in constructing social and cultural identities of Afro-Brazilian women through the naturalization of colonial practices of racial and gender domination.

In a country marked by contradictory discourses and attitudes about its racial dynamics, it is worth noting that both de Lima and Amado are examples of modernist writers committed to the project of "rediscovering" the national history, exposing the country's ambivalences and realities from the perspective of those in the margins of this history. Nonetheless, this aesthetic project reveals how the historical ambivalences and contradictions of the iconography of mestiçagem overshadow the possibilities of more liberatory literary constructions. On one hand, the characters Fulô and Gabriela break conventions in their language and attitude, because they defy, on some level, the authority of the master (in the case of Fulô) or the Christian, patriarchal moral and social codes (in the case of Gabriela). On the other hand, these representations do not overcome the masks that hide the racial and sexual conflicts in society and end up reinforcing stereotypes that paralyze the figure of the Afro-Brazilian woman (Fonseca 2002, 192-94).

Although these discourses, images, and practices were passed down through the centuries and have been incorporated in many instances of contemporary social and cultural life, the organizing, artistic, and political actions, and the scholarship developed by black women in Brazil and other parts of the diaspora have systematically tried to deconstruct these notions. By highlighting the interlocking systems of oppression affecting black women as a historical phenomenon, black women's intellectual production, especially the scholarship established in the past 40 years, has exposed racist and sexist social and cultural dynamics as destructive systems of oppression. Intellectuals and activists such as Lélia Gonzalez, Sueli Carneiro, Luiza Bairros, and Thereza Santos are pioneers in the 
analysis of the specificities of women of African descent and the particular ways in which they experience oppression in Brazil. In large part, the expansion of Brazilian black movements in the I970s and the organizing of black women's movements since the I980s have been responsible for this change. Consciousness-raising and cultural militancy have been strong components of many groups in Brazil in the struggle against racism and for a critical understanding of the country's historical process, as James $\mathrm{H}$. Kennedy (I986) points out:

It seems clear that such literary output, a natural result of growing racial consciousness, can be directly linked to shifts in the political life of the country. During the post-1964 revolution years, censorship imposed by the military regime and heavily enforced as of $\mathrm{I} 968$, together with the constant threat of police repression, successfully stifled virtually any expression of the newly awakening black consciousness among Brazilians. The major liberalization in the political order, which began in the I970s, coincided with a marked rise in black consciousness among Afro-Brazilians, as well as a growing disposition to challenge the country's racial status quo. (209).

This change in the political scenario as the pro-democracy movement gained momentum against Brazil's military regime bears witness, as Kennedy explains, to the articulation of a more visible and confrontational black movement as a national organization, following a long tradition of political struggle in different regions in the country4.In 1978 , the founding of the "Movimento Negro Unificado" (MNU, or Unified Black Movement) represented the first attempt to nationally mobilize the black population for civil rights and against cultural discrimination. This historical black civil rights struggle is depicted by writer Miriam Alves in her poem "MNU," published in 1998:

Eu sei:

Surgiu um grito na multidão

um estalo seco de

revolta

Surgiu outro

out 


$$
\begin{aligned}
& \text { ro } \\
& \text { e } \\
& \text { outros }
\end{aligned}
$$

aos poucos, amontinamos exigências

querendo o resgate

sobre nossa

forçada miséria

secular.

[I know:

There arose a shout in the crowd a dry blast of revolt

There arose another

$$
\begin{aligned}
& \text { anot } \\
& \text { her } \\
& \text { and } \\
& \text { others }
\end{aligned}
$$

little by little, we gathered demands

claiming the reparation

of our forced

secular

misery.]

Sueli Carneiro has demonstrated that black women activists, intellectuals, and artists were, by this time, fiercely questioning sexist and racist practices and discourses in both the black and women's movements and building a framework of social analysis that accounted for "the qualitative differences in oppression suffered by black women, and the effects those multiple oppressions had and still have on black women's identity (Carneiro I999, 218). In this context, many Afro-Brazilian writers fought to create spaces and conditions for the publication of their work and this period is explicitly marked by a political intervention in the art produced by these writers. The number of Afro-Brazilian women writers increased during this period, and they have played a key role in rethinking and challenging prevailing images of black women in the country ever since. 
Contemporary Afro-Brazilian Women Writers: Reclaiming the Black Female Body

As Eduardo de Assis Duarte (2005) highlights, the historical process of mestiçagem and whitening in Brazil has created a series of obstacles for the delineation of a historiography of Afro-Brazilian literary production. This impediment ranges from the strenuous difficulties in materializing the literary production and the limited circulation of materials to the deliberate erasure of authorial, or even textual, connections with the Afro-descendant ethnicity or with the modes and conditions of Afro-Brazilians (Duarte 2005, II4). For those reasons, the project of consolidating a theoretical and critical body of the Afro-Brazilian literature, in systematic development for the past 30 years, is directly associated with dismantling the notion of a unified national identity based on the ideology of mestiçagem (Duarte 2005, II3). The recovery of the work of a number of Afro-Brazilian scholars, intellectuals, and artists publishing in the shadows, at the margins of the official canons, represents the movement to deconstruct the myth of racial democracy. During the past three decades, Afro-Brazilian women writers have been committed to constructing new paradigms of cultural expression and representation, critically analyzing, deconstructing, and denouncing the forms of oppression operating on the intersections of race, gender, class, and sexuality. This articulation has allowed for the creation of new grammars of meaning and signifiers of multiple identities of black women in literature.

This is particularly evident in the publication of Cadernos Negros (Black Notebooks) and the foundation in 1980 of the editorial group Quilombhoje by black artists and intellectuals. Based in the city of São Paulo, Quilombhoje was created with the objective of deepening the discussion on the AfroBrazilian experience in literature ${ }^{5}$. First published in 1978 , Cadernos Negros was born out of the need to create a space to make Afro-Brazilian literary production visible and consumable. Ever since, Cadernos Negros has been an important space for the publication of poetry and short fiction by black writers from different parts of the country. Since its first steps, Cadernos has also been a space where black women writers figure as a significant and constant presence. Conceição Evaristo, Miriam Alves, Esmeralda Ribeiro, Geni Guimarães, Cristiane Sobral, Elisa Lucinda, Ruth de Souza Saleme, Lia 
Vieira, and Sônia Fátima are some of Afro-Brazilian women writers whose texts have been featured consistently in the volumes of this literary journal. Here, I would like to travel across some of these writers' poems and explore the possibilities they offer in order to understand their reconfigurations of the black female body according to their own voices ${ }^{6}$, operating contrary to the images of the black female body presented historically in Brazil and elsewhere in the diaspora.

Conceição Evaristo's 2008 poem "Eu-Mulher" ["I-Woman"] is not only a reaffirmation of an embodied female subjectivity and self-valorization, but it also points to the expression of sexual desire as empowerment and the valorization of the black female body as liberation. The poem also carries a set of female-centered images of the world, depicting women's creative power and nature:

Uma gota de leite

me escorre entre os seios.

Uma mancha de sangue me

enfeita entre as pernas.

Meia palavra mordida

me foge da boca.

Vagos desejos insinuam esperanças.

Eu-mulher em rios vermelhos

inauguro a vida.

Em baixa voz

violento os tímpanos do mundo.

Antevejo.

Antecipo.

Antes-vivo.

Antes-agora-o que há de vir.

Eu fêmea-matriz.

Eu força-motriz

Eu-mulher

abrigo da semente

moto-contínuo

do mundo. 
[A drop of milk

runs down between my breasts.

A stain of blood

adorns me between the legs.

Half a word choked off blazes

from my mouth.

Vague desires insinuate hopes.

I-woman in red rivers

inaugurate life.

In a low voice

I ravish the eardrums of the world.

I foresee.

I anticipate.

I live beforehand.

Before-now-what is to come.

I, the female-matrix

I, the power-motive

I-woman

shelter of the seed continual motion

of the world.]

Evaristo's use of the image of the menstrual blood as a symbol of creative power deconstructs the naturalized notion that this blood is related to impurity. Placing the female body as the matrix of the world, this metaphor also connects the female body to the idea of continuous renovation, a source of self-sustainability, resistance, intervention, and transformation. The history of slavery shows that black women's reproductive potential, like their labor, has been exploited and used to serve the interests of the colonial power. In reclaiming her body, the black female voice in the poem embraces that potential as her own power for change and creation. The poetic subject is able to live in the present (she "inaugurates life"), but she is also able to "anticipate" the future, demonstrating a profound awareness of her ability to intervene in the world. The insistent personal tone of the poetic structure-in which most verses start in the first-person-represents two important features: it reaffirms the powerful presence of the female 
voice and it also inscribes this powerful presence into the body of a black woman. Considering that authorship and literary voices are intrinsically connected as political and aesthetic expressions, Evaristo shows that her writing carries a multi-faceted perspective combining race, gender, and sexuality, creating a black female-centered metaphor.

In "Vozes-Mulheres" ["Women Voices"] (2008), Evaristo once again creates a black female-centered poetic image. Rather than an individual, this image represents diverse "women voices" gathered together to retell the history of the slavery, oppression, and suffering of black female subjects, as seen in the first four stanzas of the poem:

A voz de minha

bisavó ecoou criança

nos porões do navio.

Ecoou lamentos

de uma infância perdida.

A voz de minha avó

ecoou obediência

aos brancos-donos de tudo.

A voz de minha mãe

ecoou baixinho revolta

no fundo das cozinhas alheias

debaixo das trouxas roupagens

sujas dos brancos pelo

caminho empoeirado rumo à

favela.

A minha voz ainda ecoa

versos perplexos com

rimas de sangue

e fome.

[The voice of my grandmother echoed

a child

in the shacks of the ship.

Echoed laments 
for a lost childhood.

The voice of my grandmother echoed

obedience

to the whites-owners-of-all.

The voice of my mother

echoed, softly, revolt

in the back of others' kitchens under

the piles of

dirty clothing of the whites on

the dusty road

toward the slums.

My voice still

echoes perplexed verses

with rhymes of blood

and hunger.]

Here, Evaristo rebuilds a historical stage and channels the narrative of racial, class, and gender oppression through the voices of generations of black women. This collective component triggers the reenactment of history as an intended act of "re-memory," to use Toni Morrison's concept from Beloved (Morrison I988, 36). Like Sethe in Beloved, tracing the "echoes" of voices of her ancestors, Evaristo's poetic subject tells us about the horrors of slavery embodied in the "lost childhood" of her great-grandmother and grandmother, subjugated to the colonial power, and the reconfiguration of the same oppressive system in the lives of future generations. However, the subject's "perplexed verses" are not paralyzed by the re-memory of these horrors or the reconfigurations of racism: the final verses highlight the legacy of resistance that echoes in the embrace of all the voices in a collective action for liberation:

A voz de minha filha

recorre todas as nossas vozes

recolhe em si

as vozes mudas $\mathrm{e}$

caladas engastadas nas

gargantas. A voz de 
minha filha recolhe

em

si

a fala e o ato.

O ontem - $\mathrm{o}$ hoje - $\mathrm{o}$ agora.

$\mathrm{Na}$ voz de minha filha

se fará ouvir a

ressonância o eco da

vida-liberdade.

[The voice of my

daughter collects all of

our voices gathers in

itself

the silenced voices

choked in the

throats.

The voice of my daughter

gathers in itself

the speech and the act.

The yesterday - the today - the now.

In the voice of my daughter there will be the resonance the echo of the life-freedom.]

If the iconography of mestiçagem imposes subservience and obedience on black women, the struggles for liberation and the organizing of these women make evident that they have not conformed to this oppression. Following this tone of defiance, Esmeralda Ribeiro's "Dúvida" ["Doubt"] (1998) deconstructs the discourse of racial democracy in Brazil. By posing her doubt, the poetic voice questions the racial hierarchy that prevails in the country, according to which race, gender, and class are literally embodied by the social position the majority of black women in Brazil occupy:

Se a

margarida flor é

branca de fato

qual a cor da Margarida

que varre $\mathrm{o}$ asfalto? 
[If the daisy-

flower is white,

indeed,

what color is the Daisy

who sweeps the

road?]

A particular Brazilian cultural and socioeconomic element is significant to understanding the subtext of Ribeiro's poem. For many years, only males were hired as "garis," a popular term used to designate those who work on the cleaning (or "varrição"7) of roads and other public spaces in Brazil. The institutionalization of urban cleaning services, controlled by the state, goes back to the mid-nineteenth century, when Pedro Aleixo Gari signed the first contract for urban cleaning services with the colonial Empire. During the I970s, the city of São Paulo was the first to start to hire women for the job in massive numbers, given that large numbers of male workers were being transferred to the construction of the city's subway system. The term "margarida" became, thus, a popular urban name to refer to the women working in that sector, particularly in São Paulo city. Although there have been efforts in the past few years to bring dignity and recognition to those performing this service of social and health public utility, the position of "gari" and "margarida" is seen as one of the lowest ranked jobs someone can possibly get-it requires no formal education; it is still extremely underpaid; and it has historically been performed by masses of Afrodescendants who are kept at the margins of the country's social structures.

By playing with the word "margarida" ("daisy"), both as the flower name and a female personal name, Ribeiro is able to intersect many layers that reveal the interlocking racial, gender, and class systems of oppression operated on Afro-Brazilian women, but which are typically invisible and naturalized in Brazilian social structures. The "margarida", as a flower (a conventional symbol of delicacy, fragility, purity, and femininity) is also related to the notions of womanhood more closely connected to whiteness; while the "Margarida," as a person, is the exploited woman worker whose racial identity and oppression become invisible and naturalized in the dominant social arrangements. Ribeiro then exposes the social mask that covers the ways in which the system of oppression operates and its effects on Afro-Brazilian women, as summarized by Sueli Carneiro: "We 
are women identified as objects... Yesterday we were in the service of frail mistresses and rapacious plantation owners; today we are domestic workers for 'liberated' women and housewives or mulattas-for-export" (Carneiro 2I8, I999).

Within this context, the question posed by the poem ("qual a cor da Margaridal que varre 0 asfalto?") uncovers the ways in which racism in Brazil is combined with class and gender dynamics. The job of cleaning the streets, considered to be an inferior one, is typically performed by workers who belong to lower class statuses, which, in the Brazilian social hierarchy, are largely formed by the Afro-Brazilian population. The contrast implied by the images of the delicate white flower (daisy) and the brutal and strenuous work by the Daisy-woman (who is logically dark-skinned) is only understood when the woman's color/race is revealed by the silent and implicit answer to the question. In this way, doubt functions as a denunciation of the veiled, masked, and silenced racist rhetoric of Brazilian racial, class, and gender dynamics.

Employing the same note of denunciation, Cristiane Sobral's "Petardo" ["Petard"] (2005) highlights the impossibility of masking the reality of racial discrimination and social oppression imposed on the Afrodescendant populations since slavery—a reality that the myth of racial harmony and the discourses of mestiçagem have historically tried to veil:

Escrevi aquela estória

escura sim. Soltei meu grito

crioulo sem medo pra você

saber:

Faço questão de ser negra nessa cidade

descolorida, doa a quem doer.

Faço questão de empinar meu cabelo cheio de

poder.

Encresparei sempre,

em meio a esta noite embriagada de

trejeitos brancos e fúteis.

Escrevi aquele conto negro bem

sóbria, pra você perceber de uma vez

por todas 
que entre a minha pele e o papel que

embrulha os seus cadernos,

não há comparação parda

cabível, há um oceano,

o mesmo mar cemitério que abriga os

meus antepassados assassinados,

por essa mesma escravidão que ainda nos

oprime.

Escrevi Escrevo Escreverei

Com letras garrafais vermelho-vivo,

Pra você lembrar que jorrou muito sangue.

[Yes, I wrote that dark story.

I freed my crioulo ${ }^{8}$ shout with no fear

for you to know:

I insist on being a black woman in this discolored city, no matter who it hurts.

I insist on lifting up my hair full

of power.

I will kink it up, always,

in the middle of this inebriated night of gestures, white and futile.

Awake and sober, I wrote that black story

for you to perceive once and for all

that between my skin and the paper that wraps up

your notebooks,

there is no plausible brown comparison,

there is an ocean,

the same ocean-cemetery that shelters my

murdered ancestors,

by the same slavery that still

oppresses us.

I wrote

I write

I will write 
With upper-case bright-red letters,

For you to remember there was a flood of blood.]

As a petard, Sobral's poem is an explosive device designed to break down the walls of history. The first verses of the poem situate the black female subject and her assertive attitude toward her own sense of blackness in a "cidade descolorida" ("discolored city")—an act of self-affirmation and selfidentification expressed by the representation of the black female body. This self-positioning represents, in and of itself, an attempt to dismantle the discourses of mestiçagem designed to blur the marks of blackness.

The very act of writing a "estória escura" ("dark story") and a "conto negro" ("black story") with sobriety also represents an act of "re-memory," as is the case in Evaristo's "Vozes Mulheres." In addition, this act of (re)writing implies a level of (self) consciousness of a portion of Brazil's history that is often silenced, neglected, or dismissed. By persistently navigating across the "mar cemitério" ("ocean-cemetery), the shelter of millions of "antepassados assassinados" ("murdered ancestors"), Sobral's poem connects past and present in order to speak out about the ongoing oppression that still prevails ("essa mesma escravidão que ainda nos/ oprime"; "the same slavery that still/ oppresses us") in a social arrangement where "não há comparação parda cabível" ("there is no plausible brown comparison").

Resonating with Sueli Carneiro's observations on the objectification of Afro-Brazilian women's bodies, poet and actress Elisa Lucinda depicts a case of sexual and racial harassment in which the victim, a "mulata with green eyes," is insulted by a "white male intellectual." The poem "Mulata Exportação" ("Mulata-Export”) (2005) plays with the stereotypical representation of the hyper-sexualized mulata, so deeply incorporated and naturalized in the larger Brazilian culture. Ironically and humorously, the poetic voice, that of a "green-eyed mulata," describes the true nature of the "proposal" made by the "white male intellectual." The entire poem is constructed as a dialogue between the mulata and the white man, always playing with the dualities incorporated in the veiled intention of the proposal, the language used to refer to the mulata, and the black and white dichotomy established between the black woman and the white man:

"Mas que

nega linda E de 
olho verde ainda

Olho de veneno e açúcar!

Vem, nega, vem ser minha desculpa

$\cdots$

(Monto casa procê, mas ninguém pode saber, entendeu meu dendê?)

...

Vem ser meu folclore, vem ser minha tese sobre nego malê.

Vem, nega, vem me arrasar, depois te levo pra gente sambar."

["What a pretty nega

And a green-eyed one

Eyes of poison and honey! Come, nega,

come be my excuse

...

(I'll give you a place to dwell, but nobody should know, understand, my caramel?)

$\cdots$

Come be my folklore, my thesis about black maroons.

Come, nega, come, raze me to the ground, then we do the samba all around."]

The poem, excerpted above, presents many different layers of meanings and representations. The ideas attributed to the white male intellectual reveal one of the pillars of the ideology of mestiçagem: the notion that black women somehow find a way to uplift their social status by having a relationship with a white man. Sustained by that notion, the white male intellectual presents himself to the green-eyed mulata as the key to her social mobility ("Monto casa procê..."), although he is not willing to formalize or disclose an "official" relationship with her ("...mas ninguém pode saber, entendeu meu dendê?"). In that tradeoff, the mulata's body becomes merchandise to be consumed-its attributes are listed as treasures of a colonial conquest:

Vem ser meu álibi, minha bela conduta

Vem, nega exportação, vem meu pão de açúcar!

Minha tonteira, minha história contundida

Minha memória confundida, meu futebol, entendeu meu gelol?

Rebola bem, meu bem-querer, sou seu improviso, seu karaoquê;

Vem nega, sem eu ter que fazer nada. Vem sem ter que me mexer 
Em mim tu esqueces tarefas, favelas, senzalas, nada mais vai doer.

[Come, be my alibi, my righteous behavior

Come, nega-export, be my sugar loaf?

My vertigo, my bruised history

My confused memory, my football, understand, my menthol?

Sway well, my darling, I am your improvisation, your karaoke,

Come, nega, without me having to do a thing. Come effortlessly

With me, you will forget tasks, favelas, the quarters, nothing else will hurt.]

The mulata's awareness of this long-established dynamic arises as resistance and defiance to this historical legacy. In opposition to that colonial perspective, the poem describes the black woman's repudiation of the white man's harassment, as well as her decision to take the case to court. When all her legal resources are exhausted (resources linked to white male-dominated institutions), the black woman then turns to the judge-a symbol of the state's power-and confronts him with his inability to be fair and do justice:

Eu disse: "Seu juíz, não adianta! Opressão, Barbaridade, Genocídio, Nada disso se cura trepando com uma escura!”

[I said: "Your honor, it's no use! Oppression, Barbarity, Genocide, None of these is resolved by screwing a black woman!”]

In Lucinda's poem, the black woman's way of responding to the white man's proposition is also an act of sexual agency. Patricia Hill Collins notes that "sexuality in the individual, interpersonal domain of power becomes annexed by intersecting oppressions in the structural domain of power in order to ensure the smooth operation of domination" (Collins 2009, I85). In this sense, Lucinda is able to inscribe the sexual agency performed by the black woman in the poem as the very expression of the character's struggle for liberation - the liberation of her body as a whole. In her protest, the poetic subject's language is permeated with political and self- consciousness, revealing her understanding that the current incident and the discrimination she is subjected to are, in fact, consequences of a larger historical process. In the final verses, the black female voice of the mulata connects her present sexual harassment with the ways Afro-Brazilian black bodies have been historically perceived. The 
poem features a remarkable ending incorporating references to Gilberto Freyre's classic work:

Olha aqui, meu senhor:

Eu me lembro da senzala

e tu te lembras da Casa-Grande

e vamos juntos escrever sinceramente outra história

$\cdots$

Porque deixar de ser racista, meu

amor, não é comer uma mulata!

[Look, sir:

I remember the slave quarters

and you remember the Big House

and let's sincerely write together another story

...

Because to stop being a racist, darling,

doesn't mean fucking a mulata!]

The final lines of "Mulata-Exportação" illustrate the ultimate paradox of racial democracy inscribed on the bodies of Afro-Brazilian women: a site for desire, objectification, and exploitation, exercised within a patriarchal paradigm of domination and consumption. However, the voice of this particular mulata is the one dismantling this paradigm. Following the tradition of Afro-Brazilian resistance, she speaks truth to power: through her voice, racial and sexual oppressions are exposed as intrinsically connected with the ideology of mestiçagem; her voice makes the call for the (re)creation of a historical narrative that can lead us all to a new consciousness and the transformation of old paradigms.

\section{Conclusion}

In the article "Por Un Feminismo Afrolatinoamericano," pioneering Brazilian feminist Lélia Gonzalez presented a thorough analysis of the processes of racial, gender, and sexual discrimination in Latin America. Gonzalez's voice advocates for an Afro-Latin American feminist movement that addresses and includes specific issues affecting the lives of black and 
indigenous women in the region: "las mujeres más oprimidas y explotadas de una región de capitalismo patriarcal-racista dependiente" ["the most oppressed and exploited women in a patriarchal, racist, and capitalist region"] (Gonzalez I988, n.p.). Gonzalez's words denounce the complex racist ideology of whitening, present both in Brazil and in other parts of Latin America. They also denounce how this racist ideology is intrinsically and symbiotically combined with the sexual exploitation and gender discrimination of women of color in the Americas. Lélia Gonzalez prevails as one of the most influential voices in the subsequent struggles for equality, recognition, and liberation in the Afro-Brazilian women's movements. It is in the context of that movement of the late I970s that the writers discussed here began developing their aesthetics—and, in many cases, their activism. The selection of poems analyzed in this essay provides only a glimpse into their literary passion and political commitment to the liberation of black women's bodies beyond the flesh. Their voices defy fixed categories imposed by the iconography of mestiçagem. Their art testifies to both the history of oppression of black female bodies and the legacy of resistance to that oppression throughout the diaspora in the Americas-and beyond.

Within this context, none of the texts discussed here, nor the interpretations drawn from them, offer an easy path for this process; none of these texts provides a recipe of how to succeed in the achievement of racial and sexual liberation, consciousness, self-valorization, selfaffirmation, or the alleviation of oppression. However, in relation to the body politics with which this particular literary aesthetic is engaged, each one of these texts contributes to the understanding of the ideologies and conditions that have led Afro-descendant women, and particularly AfroBrazilian women, to feel and been seen as inferior or worthless when elements of those ideologies are culturally internalized.

The poetics of Miriam Alves, Conceição Evaristo, Esmeralda Ribeiro, Cristiane Sobral, and Elisa Lucinda offer ways by which women are able to listen to their own bodies and voices, acknowledging their beauty and the complexities of their oppression in an act of subverting a long-imposed set of degrading images of the black female body. This act of reconfiguring one's own body represents a tool with which Afro-descendant women are able to build self- consciousness, self-affirmation, and self-liberation. In addition, as cultural artifacts, these texts show that Afro-Brazilian 
female bodies are historical: on one hand, they represent the embodiment of "otherness" as they historically differ from the standards of (white) "normalcy;" on the other hand, they carry both the silenced histories of racial and sexual exploitation. By articulating their own body politics, these textual constructions re-tell history from the perspective of the "other"-a history that not only exposes the narratives of exploitation, but which opens up the possibilities of cultural reinvention and political agency for Afrodescendant women in the communities to which they belong. Above all, the political/poetic articulations discussed here re-imagine and re-create a historical narrative in which the Afro-descendant female body becomes, simultaneously, the central element from which to understand how racism and sexism are intertwined and the signifier used to inscribe in the Brazilian literature and culture images that demystify colonized notions of Afro-Brazilian women.

\section{Notes}

I. In the 1996 book More than Chattel: Black Women and Slavery in the Americas, Claire Robertson's article discusses the multi-dimensional aspect of the economics of slavery involving both Africa and the colonies in the New World. By arguing that wealth, in this context, was related to land ownership, and therefore that cheap labor recruitment was a key factor needed to increase the wealth in both places, Robertson debunks the mythical notion of an idealized free "Africa" (and Africans), affirming that Africa not only benefited from and assisted with the slave trade, but was also connected with the Americas by the trade (5-6).

2. Given the particular colonial project developed in Brazil, the term "mestiço" starts to be deployed in the early nineteenth century both as a mark of mixed-race identity and as a mark of a racially privileged group. As the project of branqueamento (whitening) gained momentum and became a political, social and economic practice enforced by the elites in power, the ideology of mestiçagem established and deepen parameters of white dominance in social hierarchies. Considering that the terms "mestiçagem" and "mestiço(a)" (or "mestizaje" and "mestizo", in Spanish) represent a historical phenomenon in Latin America, I am choosing to use these terms throughout this essay to maintain its historical specificity. For further reading on the topic see Edward Telle's Race in Another America: The Significance of Skin Color in Brazil (2004); Peter Wade's Race and Sex in Latin America (2009); and Kabengele Munanga's Rediscutindo a Mestiçagem no Brasil: Identidade Nacional Versus Identidade Negra (1999).

3. The term "cortiço," to which Azevedo's novel refers, means an area of urban housing in which many people in a family have to share a small room and live 
in severe conditions of poverty. Cortiços differ from favelas (Brazilian shantytowns) in usually being large houses divided into small rooms, rather than autonomously built poor neighborhoods. People who live in cortiços are normally families living in one very small room who have to share a single bathroom and have little or no privacy.

4. The black struggle in Brazil has a long tradition, starting with the creation of quilombos (maroon communities) throughout the country before the abolition of slavery in I888. In the early nineteenth century, a number of newspapers emerged, giving rise to an active black press, particularly in the southeast of Brazil. The "Frente Negra Brasileira" ["Black National Front"] (I930s) and the "Teatro Experimental do Negro" ["Experimental Black Theater"] (I940s) are iconic examples of organizations that had a featured role in earlier fights against racial discrimination. See Abdias Nascimento's I982 O Negro Revoltado; Clóvis Moura's I989 História do Negro Brasileiro; and Michael Hnachard's 1998 Orpheus and Power: The Movimento Negro of Rio de Janeiro and São Paulo, Brazil, 1945-1988.

5. This is a statement published by the Quilombhoje group on their website, http://www.quilombhoje.com.br/quilombhoje/historicoquilombhoje.htm, which I translate here into English. For a thorough analysis of the literature published by Quilombhoje in the volumes of Cadernos Negros, see Emanuelle K. F. Oliveira's Writing Identity: The Politics of Afro-Brazilian Literature (2007).

6. The literary texts I am quoting here are originally published in Portuguese. The translations are mine, unless otherwise indicated. Although presenting significant limitations in terms of the preservation of the literary quality of the original versions, my aim in presenting the translation here is simply to mediate the reading and the understanding of the general ideas conveyed in the texts. The translation of the poems and their titles is indicated between brackets in the body of my essay.

7. "Varrição" is a term that comes from "varrer" or literally "to sweep." The garis in Brazil's public service are often sent to urban spaces equipped with large brooms for sweeping the trash from roads and other open spaces. Because of this particular job, it became popular to say that garis do the "varrição pública" (the "public sweeping") for a city, among other cleaning and garbage collecting duties.

8. I decided to retain the Brazilian Portuguese term "crioulo" here because it is simply not possible to find an equivalent term in English for the word. While "creole" refers to a language created as a result of the contact between different languages, which is often connected with different processes of colonization (such as the creole languages of Cape Verdi or Haiti), "crioulo" in Brazil is popularly used to refer to a person of African descent, particularly someone who descends from enslaved Africans, and its use can be highly pejorative in contemporary times (a similar usage is the term "nigger" in the USA). Cristiane Sobral's poem re-signifies that term in order to affirm an African-descendant 
female identity and self-expression by using the image of a "crioulo shout" ("grito crioulo").

\section{REFERENCES}

Alves, Miriam. "MNU.” I999. In Cadernos Negros: Os Melhores Poemas, edited by Esmeralda Ribeiro, Márcio Barbosa, and Sônia Fátima, 105. São Paulo: Quilombhoje.

Caldwell, Kia Lilly. 2007. Negras in Brazil: Re-envisioning Black Women, Citizenship, and the Politics of Identity. New Brunswick, NJ: Rutgers University Press.

Carneiro, Sueli. I999. "Black Women's Identity in Brazil." In Race in Contemporary Brazil: From Indifference to Inequality, edited by Rebecca Reichmann, 2I7-28. University Park, Pennsylvania: Penn State University Press.

Collins, Patricia Hill. 2009. "Black Women's Love Relationships." In Black Feminist Thought: Knowledge, Consciousness, and the Politics of Empowerment, I6I-I86. New York/London: Routledge.

Costa, Sérgio. 200I. "A Mestiçagem e seus Contrários: Etnicidade e Nacionalidade no Brasil Contemporâneo.” Tempo Social I3 (I): I43-I58. Accessed on August 30, 2015, http://www.scielo.br/pdf/ts/vizni/vizniaio.pdf

Davies, Carole Boyce. I994. Black Women Wrting and Identity—Migrations of the Subject. New York/London: Routledge.

Duarte, Eduardo de Assis. 2005. Literatura, Política, Identidades-Ensaios. Belo Horizonte: FALE; UFMG.

Evaristo, Conceição. 2008. "Vozes-Mulheres;" "Eu-Mulher.” In Poemas da Recordação e Outros Movimentos, I0; I8. Belo Horizonte: Nandyala.

Evaristo, Conceição and Frederico, Carol. 2006. "Eu Não Sei Cantar." In Revista Raça Brasil 96. Web. Accessed on April 20, 2006.

Fonseca, Maria Nazareth Soares. 2002. "Vozes em Discordância na Literatura Afro-Brasileira Contemporânea." In Poéticas Afro-Brasileiras, edited by Maria do Carmo Lanna Figueiredo, and Maria Nazareth Soares Fonseca, I9I-220. Belo Horizonte: Mazza; PUC Minas.

Gonzalez, Lélia. 1988. "Por Un Feminismo Afrolatinoamericano.” http://www. leliagonzalez.org.br/. Accessed on October 5, 2012,

Guy-Sheftall, Beverly. 2002. "The Body Politic: Black female Sexuality and the Nineteenth Century Euro-American Imagination.” In Skin Deep, Spirit Strong: The Black Female Body in the American Culture, edited by Kimberly Wallace-Sanders, I3-36. Ann Arbor, MI: The University of Michigan Press.

hooks, bell. 199I. "Black Women Intellectuals.” In Breaking Bread: Insurgent Black Intellectual Life, edited by Cornel West and bell hooks, I47-I64. Boston: South End Press.

Kennedy, James H. 1986. "Political Liberalization, Black Consciousness, and Recent Afro- Brazilian Literature." Phylon 47 (3): I99-209. Accessed on November 9, 2008, http://www.jstor.org/stable/27498. 
Lucinda, Elisa. "Mulata-Exportação." In O Negro em Versos: Antologia da Poesia Negra Brasileira, edited by Luis Carlos dos Santos, Maria Galas, and Ulisses Tavares, 83-84. São Paulo: Moderna, 2005.

Morgan, Jennifer. 2004. "'Some Could Suckle Over Their Shoulder': Male Travelers, Female Bodies, and the Gendering of Racial Ideology." In Laboring Women:

Reproduction and Gender in New World Slavery, I2-49. Philadelphia: University of Pennsylvania Press.

Morrison, Toni. 1988. Beloved. New York: Plume Books.

Munanga, Kabengele. I999. Rediscutindo a Mestiçagem no Brasil: Identidade Nacional Versus Identidade Negra. São Paulo: Editora Vozes.

Ribeiro, Esmeralda. I998. "Dúvida." In Cadernos Negros - Os Melhores Poemas. Quilombhoje (org). São Paulo: Quilombhoje. 6r.

Sobral, Cristiane. 2005. "Petardo." In O Negro em Versos: Antologia da Poesia Negra Brasileira, edited by Luis Carlos dos Santos, Maria Galas, and Ulisses Tavares, ıo6. São Paulo: Moderna.

About the Author

Flávia Santos de Araújo earned her Master's Degree in Literature at the Federal University of Paraíba, Brazil. She is currently a Fulbright scholar and doctoral candidate at UMass Amherst, developing her research on contemporary representations of the black female body in Afro-Brazilian and U.S. Afro-American women's literature. She is also the Graduate Program Assistant at the Women of Color Leadership Network, where she develops, coordinates, and facilitates projects to address diversity and inclusion on campus. 